\title{
Effect of Mineral and Bio-Nitrogen Fertilization on Maize (Zea mays L.), some Soil Properties and Subsequent Wheat (Triticum aestivum, L.) Yield
}

\author{
Mosaad, I. S. M. ${ }^{1}$
}

\begin{abstract}
Two field experiments were conducted at El-Serw Agricultural Research Station, Damietta Governorate through summer season 2013 and winter season 2013-2014 at the same location. The aim of this study was to evaluate the effects of $\mathrm{N}$ bio-fertilization (Cyanobacteria and Cerealen) and mineral nitrogen applications $(70,140,210$ and $280 \mathrm{~kg} \mathrm{~N} \mathrm{ha}^{-1}$ ) on growth and nutrients uptake of the maize crop, and to study the residual of $\mathrm{N}$ bio fertilization on the subsequent crop (wheat) with mineral nitrogen rates $\left(0,70,140\right.$ and $\left.210 \mathrm{~kg} \mathrm{~N} \mathrm{ha}^{-1}\right)$. The results showed that Cyanobacteria inoculation $+280 \mathrm{~kg} \mathrm{~N} \mathrm{ha}^{-1}$ gave high maize plant height, maize yield and yield components as well as nutrients content and photosynthetic pigments in maize leaves. Also, the results indicated that the element $N$ at a rate of $280 \mathrm{~kg} \mathrm{~N} \mathrm{ha}^{-1}$ with Cerealen and Cyanobacteria can increase the maize grain yield by 4.14 to $19.25 \%$ and the maize stover yield by 6.89 to $16.98 \%$. Moreover, applying $\mathbf{N}$ bio-fertilizers could produce high maize grain yield when it combined with two third doses of the recommend mineral nitrogen $\left(210 \mathrm{~kg} \mathrm{~N} \mathrm{ha}{ }^{-1}\right)$. Also, there was a residual effect from $\mathrm{N}$-bio fertilizations applied to maize crop on the subsequent crop (wheat). The residual effect of Cyanobacteria inoculation on yield achieved the highest yield followed by the residual effect of Cerealen inoculations, respectively. Also, the results showed that wheat was fertilized at a rate of $140 \mathrm{~kg} \mathrm{~N} \mathrm{ha}^{-1}$ after maize cultivation inoculated with Cyanobacteria produced more wheat grain and straw yield than that fertilized with 210 $\mathrm{kg} \mathrm{N} \mathrm{ha}{ }^{-1}$, thus saving $70 \mathrm{~kg} \mathrm{~N} \mathrm{ha}^{-1}$ with a healthy and high production. Concerning to soil properties after maize harvest, Cyanobacteria surpassed Cerealen inoculations in improving soil properties, since available NPK and organic matter content had increased while soil $\mathrm{pH}$ in the root zone was decreased by using Cyanobacteria and Cerealen inoculations.
\end{abstract}

Key Words: wheat, maize, subsequent crop, bio fertilization, nitrogen, photosynthetic pigments

\section{INTRODUCTION}

The crop residue accumulates on the soil surface in agricultural soils under zero tillage. This practice improves the physical properties of soil with a slow decomposition and nitrogen immobilization by the microorganisms and little contribution of nutrients during the first stages of its decomposition. Decomposition relies on the chemical environment generated by the remains and its interaction with the microorganisms in the soil. These are mainly colonized by prokaryota and fungi. The soil microflora decompose organic compounds to obtain carbon and energy, which become a new substrate easy to degrade. The final products are carbon dioxide, mineral nutrients, humus and water (Paul and Clark, 1988).

Biological fertilizer has enormous potential for improving plant nutrition by dispensing with synthetic fertilizers for environmentally friendly agriculture. Plant growth promoting Rhizobacteria i.e. Azotobacter, Azospirillum, and phosphorus solubilizing bacteria i.e. Pseudomonas sp. and Bacillus sp. having the ability of atmospheric nitrogen fixing and solubilizing the soil phosphorus, respectively. Consequently, they fulfill the nitrogen and phosphorus requirement of cereals and improve the soil fertility. Therefore, getting crop production without causing any harmful effects on aerial and soil environment (Yasin et al., 2012).

In soils of temperate zones, the Cyanobacteria can fixa rates between 13 and $38 \mathrm{~kg} \mathrm{~N} \mathrm{ha}^{-1} \mathrm{y}^{-1}$ (Witty et al., 1979). A range of diazotrophic plant growth-promoting rhizobacteria participate in interactions with $\mathrm{C} 3$ and $\mathrm{C} 4$ crop plants (e.g. rice, wheat, maize, sugarcane and cotton), significantly increased their vegetative growth and grain yield, (Kennedy et al., 2004). Gholami, et al. (2012) reported that plant growth promoting Rhizobacteria (PGPR) plays an important role in plant health and soil fertility. Zahir, et al. (2005) revealed that application of L-tryptophan (L-TRP) or Azotobacter inoculation alone significantly affected the maize crop; however, their combined application produced more pronounced effects as compared with their separate application. Combined application of $10^{-4} \mathrm{M} \mathrm{L}^{-1} \mathrm{TRP}$ and Azotobacter significantly increased total nitrogen uptake (40\%) compared with control.

Zulpa, et al. (2008) studied the effect of cyanobacterial products of Tolypothrix tenuis and Nostoc muscorum on the microbiological activity and the nutrient content of the soil underlying the remains of maize and on the degradation of remains. They reported that the biomass and extracellular products of both strains increased the soil microbial activity such as total nitrogen $(10 \%-12 \%)$ and available phosphorus $(22 \%$ $32 \%$ ) and decreased the maize remains dry weight and

${ }^{1}$ Soils, Water and Environment Research Institute,

Agricultural Research Center, Giza, Egypt.

Corresponding author, e-mail: dribrahim1981@yahoo.com

Received September 19, 2016, Accepted October 19, 2016 
$\mathrm{C}$ content therefore $\mathrm{C}: \mathrm{N}$ ratio was closer to soil normal value.

Ghazal, et al. (2013) found that the use of Cyanobacteria inoculation (dry and spray) along with $286 \mathrm{~kg} \mathrm{~N} \mathrm{ha}^{-1}$ significantly increased maize grain yield that was not significantly different from that recorded by the use of $357 \mathrm{~kg} \mathrm{~N} \mathrm{ha}^{-1}$ alone (full recommended $\mathrm{N}$ dose). Also, the use of either Cyanobacteria or humic acide increased the soil biological activity of the plants rhizosphere.

Radwan and Nassar, (2011) indicated that the combined treatment of VAM-fungi, and Cerealen biofertilizers supported by $105.0 \mathrm{~kg} \mathrm{~N} \mathrm{ha}{ }^{-1}$, had positive significant effects on growth attributes, yield and yield components of maize hybrid cultivar, namely, threeway cross 310 (T.W. C. 310). Grzesik, et al. (2013) indicated that the used green algae and Cyanobacteria increased index of chlorophyll $\mathrm{a}+\mathrm{b}$ content in the maize leaves. Faujdar and Sharma, (2013) found that biofertilizers viz., Azotobacter, VAM and Azotobacter + VAM inoculation to maize significantly increased the grain, stover and biological yields of maize and yields of succeeding wheat grown in sequence. Applying Nbiofertilizion influenced soil properties and subsequently increased the fertility and productivity of the soil (Grzesik et al., 2013).

To get healthy and profitable production of agricultural crops there is an interest in providing necessary nutrients especially the nitrogen element. Stresses that involve deficiencies of $\mathrm{N}$ and water will adversely affect the chlorophyll amount in plants produce as well as cell turgidity (Stevenson, 1982 and Schlemmer et al., 2005). It is reported that all growth parameters of a plant were influenced by different levels of nitrogen (Faizy et al., 2011; Aminzadeh and Namazari 2013; Aarti and Tomar, 2014 and Aguilar et al., 2015).

The objective of this study was to study the response of maize and subsequent crop yields to bio and mineral nitrogen fertilization.

\section{MATERIALS AND METHODS}

\section{Experimental design and preparation.}

Two field trials were conducted at El-Serw Agricultural Research Station, Damietta Governorate at the same location. Strip-plot design with four replications was conducted in the first trial to study the effect of different $\mathrm{N}$ bio-fertilizer inoculations (the horizontal plots) (Cyanobacteria, Cerealen inoculations and control treatment) and mineral nitrogen fertilizer levels (vertical plots) $\left(70,140,210\right.$ and $280 \mathrm{~kg} \mathrm{~N} \mathrm{ha}^{-1}$, as ammonium sulphate $20 \% \mathrm{~N}$ ) on maize (Zea mays $\mathrm{CV}$. single cross $30 \mathrm{~K} 8$ ) growth and nutrients uptake. While, in the second trial, the aim was to study the effect of residual effect of $\mathrm{N}$ bio-fertilizer inoculations which were used by maize plantation (the horizontal plots) and mineral nitrogen fertilizer levels (the vertical plots) $\left(0,70,140\right.$ and $210 \mathrm{~kg} \mathrm{~N} \mathrm{ha}^{-1}$ as ammonium nitrate $33.5 \% \mathrm{~N}$ ) on sequent wheat crop (Triticum aestivum, CV. Sakha 93) growth and nutrients uptake.

Maize seeds were sown on May $27^{\text {th }}, 2013$ and its harvesting was done on $17^{\text {th }}$ October 2013. After maize harvesting, wheat seeds were sown on 10th November 2013 and its harvesting was done on 15th April.

The blue-green algae (Cyanobacteria) was provided from the soil microbiology department at Soil, Water and Environmental Institute, ARC, Giza. Algalization treatment was inoculated 5 days after planting using dry mixed culture $\left(2 \mathrm{~kg} \mathrm{ha}^{-1}\right)$ containing Anabaena Oryza, Nostoc muscrum and Tolypothrix tenuis, (El-Kholy, 1997).

Cerealen inoculant (Azospirillum spp) was provided by the Soil, Water and Environmental Institute, ARC, Giza. Bacterial inoculation in nursery bed was performed using seed coating technique. Maximum care was taken to avoid cross-contamination in the field after transplanting. Bacterial inoculation was repeated again in both nursery bed after seed sowing in the nursery bed and after planting by using liquid culture $\left(10^{9}\right.$ cells $/ \mathrm{ml}$ of bacteria) as soil application technique at a rate of 12 L.ha ${ }^{-1}$. Liquid inoculant was added 3 times during the growth period up to the flowering stage.

\section{Soil analysis.}

Surface soil samples $(0-30 \mathrm{~cm})$ were taken from the experimental field before cultivation, then air-dried and ground to pass through a $2 \mathrm{~mm}$ sieve. Soil physical and chemical properties were shown in Table 1. Particle size distribution of the composite sample was determined by hydrometer method according to Piper, (1950). Soluble cations, anions and total soluble salts were estimated in 1:5 soil water extract, while the organic matter was determined by using Walkley and Black method, but available potassium was extracted by neutral normal ammonium acetate $\left(\mathrm{C}_{2} \mathrm{H}_{3} \mathrm{O}_{2} \mathrm{NH}_{4}\right)$ and $\mathrm{K}$ was measured by a flame photometer as described by Jackson, (1967). Soluble $\mathrm{SO}_{4}^{-2}$ was taken as the difference between the summation of soluble cations and anions. The $\mathrm{pH}$ values were measured in 1: 2.5 soil-water suspensions according to Jackson, (1973). 
Table 1. Physical and chemical properties of the soil samples before maize cultivation in 2013 growing season

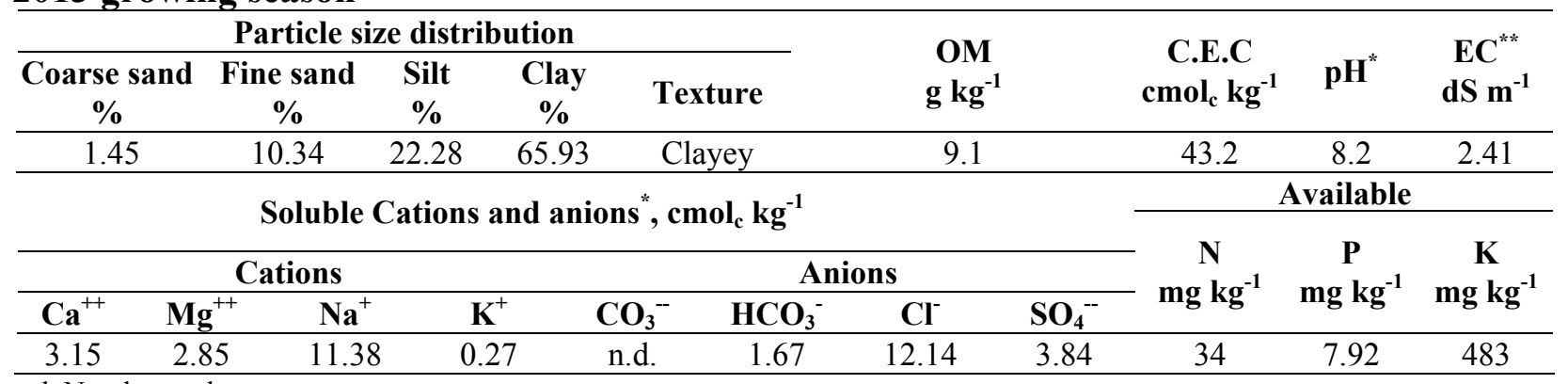

n.d. Not detected.

* in the soil-water suspensions (1:2.5).

** in the soil extract (1:5).

Available nitrogen was determined in the soil extracted using Potassium Sulfate $\left(\mathrm{K}_{2} \mathrm{SO}_{4}\right)$ and determined by using macro Kjell-dhal according to Hesse (1971). Available phosphorus was extracted by sodium bicarbonate $\left(\mathrm{NaHCO}_{3}\right)$ of $\mathrm{pH} \quad 8.5$ and determined colorimetrically according to Olsen, and Dean (1965).

At the end of first experiment (maize), composite soil samples were taken from the upper layer $(30 \mathrm{~cm})$ from each plot, after harvesting of maize to determine some chemical properties such as available N, P and K, OM, EC, and Soil pH.

\section{Plant analysis.}

\section{Photosynthetic pigments estimation.}

Photosynthetic pigments (Chlorophyll a, Chlorophyll $b$ and Carotenoids) were determined at the booting stage for maize and wheat plants. A $250 \mathrm{mg}$ fresh leaves which were homogenized with $80 \%$ acetone, centrifuged at $4000 \mathrm{rpm}$, for 5 minutes. The filtrate was taken out and final $25 \mathrm{ml}$ volume was made by using $80 \%$ acetone. Optical density was read at 480 , $510,645,652$ and $663 \mathrm{~nm}$ with spectrophotometer. The chlorophyll content was estimated by the formulae given by Arnon (1949) which are expressed below:

Chl. 'a' $\mathrm{mg} \mathrm{g}^{-1}=12.7$ (OD663) - 2.69 (OD645) $\mathrm{x}$ $\mathrm{V} / 1000 \times \mathrm{W}$

Chl. 'b' $\mathrm{mg} \mathrm{g}^{-1}=22.9($ OD645) $-4.68($ OD663) $\mathrm{x}$ $\mathrm{V} / 1000 \times \mathrm{W}$

Carotenoid $\mathrm{mg} \mathrm{g}^{-1}=7.6(\mathrm{OD} 480)-1.49$ (OD 510) $\mathrm{X}$ $\mathrm{v} / 1000 \mathrm{X} \mathrm{W}$

Where $\mathrm{OD}=$ Optical density, $\mathrm{V}=$ Final vol. of $80 \%$ acetone $(25 \mathrm{ml})$ and $\mathrm{W}=\mathrm{Wt}$. of sample taken $(0.25 \mathrm{~g})$.

Plant growth parameters and yield.

Plant height $(\mathrm{cm})$, weight of 100 grain $(\mathrm{g})$ for maize and 1000 grain $(\mathrm{g})$ for wheat, grain yield $\left(\mathrm{t} \mathrm{ha}^{-1}\right)$, maize stover and wheat straw yield $\left(\mathrm{t} \mathrm{ha}^{-1}\right)$ were recorded after maize and wheat harvest.

\section{Macronutrients analysis:}

$\mathrm{N}, \mathrm{P}$ and $\mathrm{K}$ uptake in maize grains and stover and wheat grain and straw were calculated by the following equation:

Nutrient element uptake $\mathrm{kg} \mathrm{ha}^{-1}$

$$
=\frac{\text { Nutrient element } \% \times \text { Yield }(\mathrm{kg} / \mathrm{ha})}{100}
$$

Oven-dried samples of maize (grain and stover) and wheat (grain and straw) were ground in a mill using a 50 -mesh screen. These samples were digested in concentrated $\mathrm{H}_{2} \mathrm{SO}_{4}$ and $\mathrm{H}_{2} \mathrm{O}_{2} 30 \%$, according to Yash (1998). Nitrogen content was determined by using the micro kjell-dhal method, while phosphorus percentage was colorimetrically determined using chlorostannusreduced molybdophosphoric blue colour method, in hydrochloric acid system and potassium concentration was measured by the flame photometer (Jackson, 1967).

\section{The statistical analysis.}

Data were collected to statistical analysis according to Snedecor and Cochran (1967). Mean values were compared at the $5 \%$ and $1 \%$ levels of significance by using the Least Significance Difference (LSD) test. CoHort Software (2008) was used for statistical data analysis.

\section{RESULTS AND DISCUSSION}

Effect of mineral and bio-fertilization of nitrogen on maize:

\section{Nitrogen application:}

Nitrogen treatments significantly increased photosynthetic pigment contents (Chlorophyll a, Chlorophyll $\mathrm{b}$ and Carotenoids) in maize leaves at the booting stage in the 2013 season (Table 2). 
Table 2. Photosynthetic pigments content (Chlorophyll a, Chlorophyll b and Carotenoids) $\left(\mathrm{mg} \mathrm{g}^{-1}\right)$ in maize leaves at the booting stage as affected by nitrogen application rates, different inoculations with $\mathrm{N}$ bio-fertilization $\left(\mathrm{I}_{0}=\right.$ control, $\mathrm{I}_{1}=$ Cyanobacteria and $\mathrm{I}_{2}=$ Cerealen treatment) and their interaction

\begin{tabular}{|c|c|c|c|c|c|c|c|c|c|c|c|c|}
\hline \multirow[b]{2}{*}{ Treatments } & \multicolumn{4}{|c|}{ Chl. a $\left(\mathrm{mg} \mathrm{g}^{-1}\right)$} & \multicolumn{4}{|c|}{ Chl. b (mg g $\left.{ }^{-1}\right)$} & \multicolumn{4}{|c|}{ Carotenoids $\left(\mathrm{mg} \mathrm{g}^{-1}\right)$} \\
\hline & $\mathbf{I}_{\mathbf{0}}$ & $\mathbf{I}_{1}$ & $\mathbf{I}_{2}$ & $\begin{array}{l}\vdots \\
\frac{\Xi}{z} \\
z\end{array}$ & $\mathbf{I}_{\mathbf{0}}$ & $\mathbf{I}_{1}$ & $\mathbf{I}_{2}$ & $\underset{z}{\Sigma}$ & $\mathbf{I}_{\mathbf{0}}$ & $\mathbf{I}_{1}$ & $\mathbf{I}_{2}$ & $\frac{\Sigma}{\Sigma}$ \\
\hline $\mathrm{N}_{70}$ & 14.44 & 25.56 & 19.62 & 19.87 & 2.79 & 3.77 & 3.04 & 3.20 & 124.65 & 211.67 & 152.56 & 162.96 \\
\hline $\mathrm{N}_{140}$ & 20.16 & 28.47 & 25.81 & 24.81 & 5.08 & 6.75 & 5.42 & 5.75 & 148.98 & 344.27 & 286.37 & 259.87 \\
\hline $\mathrm{N}_{210}$ & 27.37 & 33.11 & 28.24 & 29.57 & 4.77 & 8.21 & 7.65 & 6.88 & 375.17 & 453.90 & 436.37 & 421.81 \\
\hline $\mathrm{N}_{280}$ & 35.12 & 36.16 & 34.43 & 35.24 & 8.44 & 10.42 & 9.52 & 9.46 & 482.27 & 665.60 & 577.40 & 575.09 \\
\hline I Mean & 24.27 & 30.83 & 27.03 & & 5.27 & 7.29 & 6.41 & & 282.77 & 418.86 & 363.18 & \\
\hline$F$. test & \multicolumn{4}{|c|}{$* *$} & \multicolumn{4}{|c|}{$* *$} & \multicolumn{4}{|c|}{$* *$} \\
\hline$L S D 5 \%$ & \multicolumn{4}{|c|}{0.141} & \multicolumn{4}{|c|}{0.055} & \multicolumn{4}{|c|}{3.779} \\
\hline$L S D 1 \%$ & \multicolumn{4}{|c|}{0.193} & \multicolumn{4}{|c|}{0.075} & \multicolumn{4}{|c|}{5.178} \\
\hline \multirow{2}{*}{$\begin{array}{ll}\text { F. test } & \mathrm{I} \\
\end{array}$} & \multicolumn{4}{|c|}{$* *$} & \multicolumn{4}{|c|}{$* *$} & \multicolumn{4}{|c|}{$* *$} \\
\hline & \multicolumn{4}{|c|}{$* *$} & \multicolumn{4}{|c|}{$* *$} & \multicolumn{4}{|c|}{$* *$} \\
\hline
\end{tabular}

*Significant at $5 \%$ level. $\quad * *$ Significant at $1 \%$ level.

$\mathrm{I}=$ Bio-fertilization Inoculations $\quad \mathrm{I}_{0}=$ Control treatment. $\mathrm{N}=$ Meneral Nitrogen Fertilization $\mathrm{N}_{70}=70 \mathrm{~kg} \mathrm{~N} \mathrm{ha}^{-1}$. $\mathrm{ha}^{-1} \cdot \mathrm{N}_{280}=280 \mathrm{~kg} \mathrm{~N} \mathrm{ha}^{-1}$.

These increases could be attributed to the positive relationship between photosynthetic contents in plant leaves and nitrogen content, because of element of nitrogen enters into the composition of enzymes for photosynthesis processes in the chlorophyll molecule thus increasing nitrogen fertilization leads to increased content of leaves from photosynthesis pigments. Kopsell, et al. (2004) reported that nitrogen fertilization is the most important factors indicating the efficiency of the performance of the photosynthetic apparatus that determines photosynthetic pigment contents in leaves.

Table (3) showed that maize plant height, maize yield (grain and stover), 100-grain weight increased with increasing nitrogen application up to $280 \mathrm{~kg} \mathrm{~N}^{-}$ 1 . It is worthy to mention that the maize was cultivated after cereals (wheat) so, nitrogen application had a great increment of grain and stover yield, i.e. maize plants significantly responded more for nitrogen application under its deficiency (Table 3). Table (4) is refers to increase of NPK uptake in maize grain, and stover with increasing nitrogen application up to $280 \mathrm{~kg} \mathrm{~N} \mathrm{ha}^{-1}$. Availability and internal distribution of nitrogen element play a critical role in the regulation of various growth-related and morphogenetic aspects of plant development (McIntyre, 2001). Several researchers came to the same results (Aminzadeh and Namazari, 2013; Aarti and Tomar, 2014 and Aguilar et al., 2015).
$\mathrm{I}_{1}=$ Cyanobacteria treatment. $\mathrm{I}_{2}=$ Cerealen treatment.

$\mathrm{N}_{140}=140 \mathrm{~kg} \mathrm{~N} \mathrm{ha}^{-1} . \quad \mathrm{N}_{210}=210 \mathrm{~kg} \mathrm{~N}$

\section{Bio-fertilization of nitrogen:}

Table (2) showed to a significant increase in photosynthetic pigment contents in maize leaves at booting stage due to nitrogen bio fertilizations and the highest values of photosynthetic pigments were obtained by Cyanobacteria followed by Cerealen inoculations, respectively. Biological fertilization is the perfect solution for replacement of mineral nitrogen fertilizer for its important and effective in the fixation of air nitrogen in the soil to be available to plant nutrition after the decomposition of microorganisms after its death. Amongst the nutrients, nitrogen is the only nutrient, which plays a major role in the synthesis of chlorophyll, amino acids and protein building blocks (Mahato et al., 2009). As in the mineral $\mathrm{N}$ fertilization effect on the content of the leaves of photosynthesis pigments, where there was a direct correlation between the mineral $\mathrm{N}$ fertilization and content of leaves of photosynthesis pigments. As $\mathrm{N}$ bio-fertilization leads to increased soil nitrogen content available to plant, leads to increased leaf content of photosynthetic pigments, so there is a direct correlation between biological $\mathrm{N}$ and content leaves of photosynthetic pigments. 
Table 3. Plant high (cm), 100-grains weight (g), grain yield $\left(\mathrm{t} \mathrm{ha}^{-1}\right)$ and stover yield (t ha $\left.\mathrm{h}^{-1}\right)$ of maize as affected by nitrogen application rates, inoculations with $\mathbf{N}$ bio-fertilization $\left(\mathrm{I}_{0}=\right.$ control, $\mathrm{I}_{1}=$ Cyanobacteria, and $\mathrm{I}_{2}=$ Cerealen treatment $)$ and their interaction Plant height (cm) 100-grain weight $(\mathrm{g}) \quad$ Grain yield $\left(\mathrm{t} \mathrm{ha}^{-1}\right)$

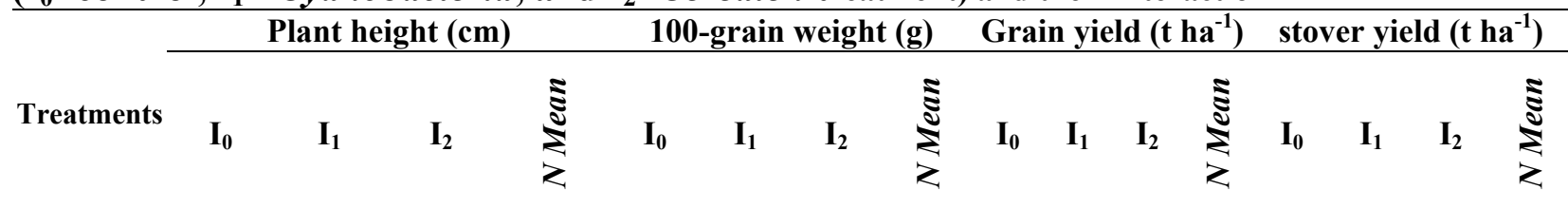

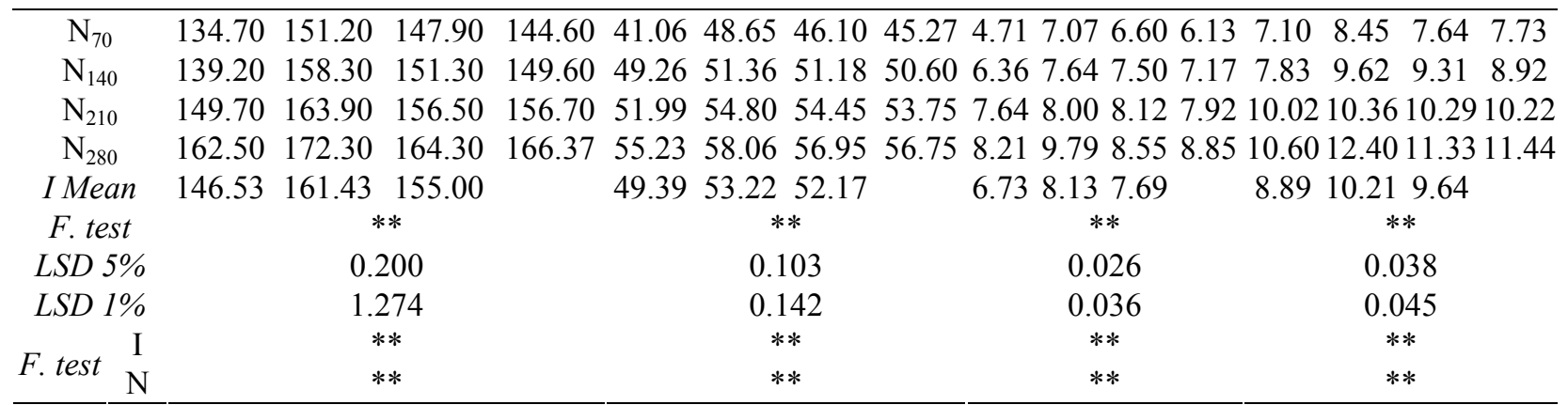

*Significant at $5 \%$ level. $\quad * *$ Significant at $1 \%$ level.

$\mathrm{I}=$ Bio-fertilization Inoculations $\quad \mathrm{I}_{0}=$ Control treatment $\mathrm{N}=$ Meneral Nitrogen Fertilization $\quad \mathrm{N}_{70}=70 \mathrm{~kg} \mathrm{~N} \mathrm{ha}^{-1}$. $\mathrm{N}_{280}=280 \mathrm{~kg} \mathrm{~N} \mathrm{ha}^{-1}$.

Table (3) showed that maize plant height, maize grain and stover yield, 100-grain weight. Data in Table (4) show that NPK uptake of maize grain and stover increased by applying $\mathrm{N}$ bio-fertilizer inoculations and the highest values of these previous parameters were obtained by Cyanobacteria and Cerealen, respectively. These increases could be attributed to high efficiency, which was shown by $\mathrm{N}$ bio-fertilizations in fixing of atmospheric nitrogen, therefore increasing in maize grain and straw yield. Ravikumara et al., (2004); Aminzadeh and Namazari, (2013) and Aguilar, et al. (2015) obtained close result when they applied biological nitrogen fertilization on maize.

\section{The interaction effect:}

There was a significant interaction effect between nitrogen application and $\mathrm{N}$ bio-fertilizer inoculation on photosynthetic pigments content in maize leaves at booting stage (Table 2). The highest values of photosynthetic pigments contents in maize leaves at the booting stage were obtained with Cyanobacteria inoculation and $280 \mathrm{~kg} \mathrm{~N}^{-1}$ treatment followed by Cerealen inoculations and $280 \mathrm{~kg} \mathrm{~N} \mathrm{ha}{ }^{-1}$. In addition, there was a significant interaction effect on maize plant height, maize grain and stover yield, 100-grain weight (Table 3) and NPK uptake in maize grain and stover (Table 4) and the highest values of these parameters were obtained by Cyanobacteria $+280 \mathrm{~kg} \mathrm{~N} \mathrm{ha}^{-1}$. The application of element $\mathrm{N}$ at a rate of $280 \mathrm{~kg} \mathrm{~N} \mathrm{ha}^{-1}$ with Cerealen and Cyanobacteria, can increase the maize
$\mathrm{I}_{1}=$ Cyanobacteria treatment. $\mathrm{I}_{2}=$ Cerealen treatment. $\mathrm{N}_{140}=140 \mathrm{~kg} \mathrm{~N} \mathrm{ha}^{-1} . \quad \mathrm{N}_{210}=210 \mathrm{~kg} \mathrm{~N} \mathrm{ha}^{-1}$.

grain yield by 4.14 to $19.25 \%$ and the maize stover yield by 6.89 to $16.98 \%$. These results may be explained on the basis that the promoting effects of biofertilizer and nitrogen together on maize growth were reflected in the increased of all previous parameters. Sachin and Misra, (2009) mentioned that in present research work Azotobacter chroococcum was used to study their effect on the growth of Maize.

Effect of nitrogen application, residual effect of previous $\mathbf{N}$ bio-fertilizations and their interaction on wheat:

\section{Nitrogen application:}

Table (5) revealed that nitrogen application significantly increased photosynthetic pigment contents (chlorophyll a, chlorophyll $\mathrm{b}$ and carotenoids) in wheat leaves at booting stage in 2013/2014 season and high photosynthetic pigments were obtained by $210 \mathrm{~kg} \mathrm{~N} \mathrm{ha}^{-}$ 1 . This increase in wheat leaf content of photosynthetic pigments was due to the direct impact of nitrogen fertilization on plant nitrogen content which affects on leaf content of photosynthetic pigments to enter the nitrogen component in the installation of chlorophyll molecules and involvement in many physiological processes within the molecule of chlorophyll. Similar results were obtained by Aishwath et al., (2003).

Table (6) reported that application of nitrogen fertilizer significantly increased wheat plant height, wheat grain and straw yield and 1000-grain weight up to $210 \mathrm{~kg} \mathrm{~N} \mathrm{ha}^{-1}$. 
Table 4. The amount of $\mathrm{N}, \mathrm{P}$ and $\mathrm{K}$ uptake $\left(\mathrm{kg} \mathrm{ha}^{-1}\right)$ by maize grain and stover as affected by nitrogen application rates, different inoculations with $\mathrm{N}$ bio-fertilization $\left(\mathrm{I}_{0}=\right.$ control, $\underline{I_{1}}=$ Cyanobacteria and $I_{2}=$ Cerealen treatment) and their interaction

N-uptake $\mathrm{kg} \mathrm{ha}^{-1} \quad \begin{aligned} & \text { P-uptake } \mathrm{kg} \mathrm{ha}^{-1} \\ & \text { Grains of Maize }\end{aligned}$

K-uptake $\mathrm{kg} \mathrm{ha}^{-1}$

Grains of Maize

\begin{tabular}{|c|c|c|c|c|c|c|c|c|c|c|c|c|}
\hline Treatments & $\mathbf{I}_{0}$ & $\mathbf{I}_{1}$ & $\mathbf{I}_{2}$ & $\begin{array}{l}\tilde{\Xi} \\
z \\
z\end{array}$ & $\mathbf{I}_{0}$ & $\mathbf{I}_{1}$ & $\mathbf{I}_{2}$ & $\begin{array}{l}\tilde{\Xi} \\
z \\
z\end{array}$ & $\mathbf{I}_{0}$ & $\mathbf{I}_{1}$ & $\mathbf{I}_{2}$ & $\begin{array}{l}\tilde{\Xi} \\
\text { ż } \\
z\end{array}$ \\
\hline $\mathrm{N}_{70}$ & 69.07 & 125.36 & 116.69 & 103.71 & 13.31 & 19.31 & 16.64 & 16.42 & 5.38 & 12.45 & 11.10 & 9.64 \\
\hline $\mathrm{N}_{140}$ & 95.21 & 133.79 & 119.02 & 116.01 & 16.55 & 23.38 & 17.21 & 19.05 & 7.40 & 23.69 & 19.02 & 16.70 \\
\hline $\mathrm{N}_{210}$ & 107.64 & 143.14 & 131.45 & 127.41 & 16.93 & 26.48 & 23.71 & 22.37 & 11.88 & 31.45 & 28.52 & 23.95 \\
\hline $\mathrm{N}_{280}$ & 142.83 & 163.21 & 147.60 & 151.21 & 18.26 & 30.57 & 24.95 & 24.59 & 17.19 & 36.95 & 33.83 & 29.32 \\
\hline I Mean & 103.69 & 141.38 & 128.69 & & 16.26 & 24.94 & 20.63 & & 10.46 & 26.14 & 23.12 & \\
\hline F.test & \multicolumn{4}{|c|}{$* *$} & \multicolumn{4}{|c|}{$* *$} & \multicolumn{4}{|c|}{$* *$} \\
\hline$L S D 5 \%$ & \multirow{2}{*}{\multicolumn{4}{|c|}{$\begin{array}{l}0.445 \\
0.610\end{array}$}} & \multirow{2}{*}{\multicolumn{4}{|c|}{$\begin{array}{l}0.026 \\
0.036\end{array}$}} & \multicolumn{4}{|c|}{0.300} \\
\hline$L S D 1 \%$ & & & & & & & & & \multicolumn{4}{|c|}{0.412} \\
\hline F. test $\mathrm{I}$ & \multicolumn{4}{|c|}{$* *$} & \multicolumn{4}{|c|}{$* *$} & \multicolumn{4}{|c|}{$* *$} \\
\hline
\end{tabular}

stover of Maize

\begin{tabular}{|c|c|c|c|c|c|c|c|c|c|c|c|c|}
\hline Treatments & $\mathbf{I}_{0}$ & $\mathbf{I}_{1}$ & $\mathbf{I}_{2}$ & $\frac{\Xi}{z}$ & $\mathbf{I}_{0}$ & $\mathbf{I}_{1}$ & $\mathbf{I}_{2}$ & $\begin{array}{l}\mathbf{\Xi} \\
z \\
z\end{array}$ & $\mathbf{I}_{0}$ & $\mathbf{I}_{1}$ & $\mathbf{I}_{2}$ & $\begin{array}{l}\mathbf{\Sigma} \\
z \\
z\end{array}$ \\
\hline $\mathrm{N}_{70}$ & 2.12 & 4.57 & 3.38 & 3.36 & 0.57 & 2.60 & 2.26 & 1.81 & 14.57 & 22.31 & 19.38 & 18.75 \\
\hline $\mathrm{N}_{140}$ & 2.48 & 5.12 & 3.60 & 3.73 & 1.02 & 2.86 & 2.40 & 2.09 & 16.93 & 39.14 & 24.36 & 26.81 \\
\hline $\mathrm{N}_{210}$ & 3.67 & 5.98 & 4.33 & 4.66 & 2.10 & 3.07 & 2.74 & 2.64 & 19.74 & 86.00 & 41.02 & 48.92 \\
\hline $\mathrm{N}_{280}$ & 4.50 & 6.95 & 4.64 & 5.36 & 2.43 & 3.21 & 2.88 & 2.84 & 23.79 & 97.60 & 55.02 & 58.80 \\
\hline I Mean & 3.19 & 5.66 & 3.99 & & 1.53 & 2.94 & 2.57 & & 18.76 & 61.26 & 34.95 & \\
\hline F.test & \multicolumn{4}{|c|}{$* *$} & \multicolumn{4}{|c|}{$* *$} & \multicolumn{4}{|c|}{$* *$} \\
\hline$L S D 5 \%$ & \multirow{2}{*}{\multicolumn{4}{|c|}{0.024}} & \multirow{2}{*}{\multicolumn{4}{|c|}{0.012}} & \multicolumn{4}{|c|}{0.474} \\
\hline$L S D 1 \%$ & & & & & \multicolumn{2}{|c|}{0.017} & & & \multicolumn{4}{|c|}{0.650} \\
\hline I & \multirow{2}{*}{\multicolumn{4}{|c|}{$\begin{array}{l}* * \\
* *\end{array}$}} & \multirow{2}{*}{\multicolumn{4}{|c|}{$\begin{array}{l}* * \\
* *\end{array}$}} & \multirow{2}{*}{\multicolumn{4}{|c|}{$\begin{array}{l}* * \\
* *\end{array}$}} \\
\hline F. test $\quad \mathrm{N}$ & & & & & & & & & & & & \\
\hline
\end{tabular}

*Significant at $5 \%$ level. $\quad * *$ Significant at $1 \%$ level.

$\mathrm{I}=$ Bio-fertilization Inoculations $\quad \mathrm{I}_{0}=$ Control treatment. $\quad \mathrm{I}_{1}=$ Cyanobacteria treatment. $\mathrm{I}_{2}=$ Cerealen treatment.

$\mathrm{N}=$ Meneral Nitrogen Fertilization $\quad \mathrm{N}_{70}=70 \mathrm{~kg} \mathrm{~N} \mathrm{ha}^{-1} . \mathrm{N}_{140}=140 \mathrm{~kg} \mathrm{~N} \mathrm{ha}^{-1} . \quad \mathrm{N}_{210}=210 \mathrm{~kg} \mathrm{~N} \mathrm{ha}^{-1}$.

$\mathrm{N}_{280}=280 \mathrm{~kg} \mathrm{~N} \mathrm{ha}^{-1}$.

Also, the effect of nitrogen applications on the NPK uptake in wheat grain, and straw were increased significantly by increasing nitrogen rate up to $210 \mathrm{~kg} \mathrm{~N}$ ha $^{-1}$ (Table 7). The increment in grain yield due to nitrogen fertilizer may be attributed to increase in most correlated yield components, which increase the final yield. These findings correspond to those reported by Sushila and Gajendra (2000).

\section{Residual effect of $\mathbf{N}$ bio-fertilization:}

Table (5) showed a significant increase in photosynthetic pigment contents in wheat leaves at booting stage due to the residual effect of $\mathrm{N}$ bio- fertilization, where the residual effect of Cyanobacteria inoculation gave superior results following by the residual effect of Cerealen inoculation. The increases in photosynthetic pigments in wheat leaves at the booting stage as affected by the residual effect of $\mathrm{N}$ biofertilizer inoculations could be attributed to a positive relationship between photosynthetic contents in plant leaves and nitrogen content in this plant which could be increased due to organic matter produced by $\mathrm{N}$ biofertilizer inoculations and nutrient elements such as nitrogen released from histolysis of organic matter. 
Table 5. Photosynthetic pigment contents (Chlorophyll a, Chlorophyll b and Carotenoids; $\mathrm{mg} \mathrm{g}^{-1}$ ) in wheat leaves at the booting stage as affected by nitrogen application rates, the residual effect of different inoculations with $\mathrm{N}$ bio-fertilization: $\left(\mathrm{RI}_{\mathbf{0}}=\right.$ control, $\mathrm{RI}_{1}=\mathrm{Residual}$ effect of Cyanobacteria and $\mathrm{RI}_{2}=$ Residual effect of Cerealen treatment) and their interaction $\begin{array}{lll}\text { Chl. a }\left(\mathrm{mg} \mathrm{g}^{-1}\right) & \text { Chl. b }\left(\mathrm{mg} \mathrm{g}^{-1}\right) & \text { Carotenoids }\left(\mathrm{mg} \mathrm{g}^{-1}\right)\end{array}$

\begin{tabular}{|c|c|c|c|c|c|c|c|c|c|c|c|c|}
\hline \multirow[b]{2}{*}{ Treatments } & \multicolumn{4}{|c|}{ Chl. a (mg g ) } & \multicolumn{4}{|c|}{ Chl.b (mg g ) } & \multicolumn{4}{|c|}{ Carotenoids ( mg g ) } \\
\hline & $\mathbf{R} \mathbf{I}_{\mathbf{0}}$ & $\mathbf{R I}_{1}$ & $\mathbf{R I}_{2}$ & $\begin{array}{l}\tilde{\Xi} \\
z \\
z\end{array}$ & $\mathbf{R I}_{\mathbf{0}}$ & $\mathbf{R I}_{1}$ & $\mathbf{R} \mathbf{I}_{2}$ & $\begin{array}{l}\tilde{\Xi} \\
z \\
z\end{array}$ & $\mathbf{R \mathbf { I } _ { 0 }}$ & $\mathbf{R I}_{1}$ & $\mathbf{R} \mathbf{I}_{2}$ & $\frac{\Sigma}{z}$ \\
\hline $\mathrm{N}_{0}$ & 1.777 & 2.893 & 2.261 & 2.310 & 1.257 & 1.845 & 1.687 & 1.596 & 0.851 & 1.741 & 1.371 & 1.321 \\
\hline $\mathrm{N}_{70}$ & 2.372 & 4.601 & 3.973 & 3.649 & 1.376 & 2.090 & 1.816 & 1.761 & 0.994 & 1.878 & 1.762 & 1.545 \\
\hline $\mathrm{N}_{140}$ & 5.141 & 6.943 & 6.439 & 6.174 & 2.279 & 3.002 & 2.788 & 2.690 & 1.947 & 2.039 & 2.025 & 2.004 \\
\hline $\mathrm{N}_{210}$ & 7.211 & 8.291 & 7.884 & 7.795 & 3.240 & 4.967 & 3.893 & 4.033 & 2.061 & 2.647 & 2.175 & 2.294 \\
\hline RI Mean & 4.125 & 5.682 & 5.139 & & 2.038 & 2.976 & 2.546 & & 1.463 & 2.076 & 1.833 & \\
\hline F. test & \multicolumn{4}{|c|}{$* *$} & \multicolumn{4}{|c|}{$* *$} & \multicolumn{4}{|c|}{$* *$} \\
\hline LSD 5\% & \multirow{2}{*}{\multicolumn{4}{|c|}{$\begin{array}{l}0.051 \\
0.070\end{array}$}} & \multirow{2}{*}{\multicolumn{4}{|c|}{$\begin{array}{l}0.024 \\
0.032\end{array}$}} & \multicolumn{4}{|c|}{0.010} \\
\hline$L S D 1 \%$ & & & & & & & & & \multicolumn{4}{|c|}{0.013} \\
\hline \multirow{2}{*}{ F. test } & \multicolumn{4}{|c|}{$* *$} & \multicolumn{4}{|c|}{$* *$} & \multirow{2}{*}{\multicolumn{4}{|c|}{$* *$}} \\
\hline & \multicolumn{4}{|c|}{$* *$} & \multicolumn{4}{|c|}{$* *$} & & & & \\
\hline
\end{tabular}

*Significant at 5\% level. $\quad * *$ Significant at $1 \%$ level.

$\mathrm{RI}=$ Residual effect of Bio-fertilization Inoculations $\quad \mathrm{RI}_{0}=$ Control treatment.

$\mathrm{RI}_{1}=$ Residual effect of Cyanobacteria treatment. $\quad \mathrm{RI}_{2}=$ Residual effect of Cerealen treatment.

$\mathrm{N}=$ Mineral Nitrogen Fertilization $\quad \mathrm{N}_{0}=0 \mathrm{~kg} \mathrm{~N} \mathrm{ha}^{-1} . \quad \mathrm{N}_{70}=70 \mathrm{~kg} \mathrm{~N} \mathrm{ha}^{-1} . \quad \mathrm{N}_{140}=140 \mathrm{~kg} \mathrm{~N} \mathrm{ha}^{-1}$.

$\mathrm{N}_{210}=210 \mathrm{~kg} \mathrm{~N} \mathrm{ha}^{-1}$.

Table 6. Plant high (cm), 1000-grains weight (g) grain yield and straw yield $\left(\mathrm{t} \mathrm{ha}^{-1}\right)$ of wheat as affected by nitrogen application rates for wheat, the residual effect of different inoculations with $\mathrm{N}$ bio-fertilization: $\left(\mathrm{RI}_{0}=\right.$ control, $\mathrm{RI}_{1}=$ Residual effect of Cyanobacteria and $R_{2}=$ Residual effect of Cerealen treatment) and their interaction

\begin{tabular}{|c|c|c|c|c|c|c|c|c|c|c|c|c|c|c|c|c|}
\hline \multirow[b]{2}{*}{ Treatments } & \multicolumn{4}{|c|}{ Plant height (cm) } & \multicolumn{4}{|c|}{ 1000-grain weight $(\mathrm{g})$} & \multicolumn{4}{|c|}{ Grain yield $\left(\mathrm{t} \mathrm{ha}^{-1}\right)$} & \multicolumn{4}{|c|}{ Straw yield $\left(\mathrm{t} \mathrm{ha}^{-1}\right)$} \\
\hline & $\mathbf{R \mathbf { I } _ { 0 }}$ & $\mathbf{R I}_{1}$ & $\mathbf{R I}_{2}$ & $\sum_{z}^{\mathbb{z}}$ & $\mathbf{R} \mathbf{I}_{\mathbf{0}}$ & $\mathbf{R I}_{1}$ & $\mathbf{R I}_{\mathbf{2}}$ & $\sum_{z}^{\mathfrak{\Xi}}$ & $\mathbf{R} \mathbf{I}_{\mathbf{0}}$ & $\mathbf{R I}_{1}$ & $\mathbf{R I}_{\mathbf{2}}$ & $\sum_{z}^{\Sigma}$ & $\mathbf{R} \mathbf{I}_{\mathbf{0}}$ & $\mathbf{R I}_{1}$ & $\mathbf{R} \mathbf{I}_{2}$ & $\sum_{z}^{\mathbb{Z}}$ \\
\hline $\mathrm{N}_{0}$ & 67.20 & 75.30 & 72.90 & 71.80 & 13.72 & 14.89 & 14.55 & 14.39 & 2.02 & 3.29 & 2.81 & 2.71 & 2.40 & 5.57 & 4.74 & 4.24 \\
\hline $\mathrm{N}_{70}$ & 79.10 & 82.60 & 81.50 & 81.07 & 15.33 & 17.89 & 17.64 & 16.95 & 3.57 & 4.60 & 4.29 & 4.15 & 6.14 & 7.93 & 7.26 & 7.11 \\
\hline $\mathrm{N}_{140}$ & 83.80 & 86.90 & 86.40 & 85.70 & 18.22 & 18.77 & 18.59 & 18.53 & 4.79 & 6.10 & 5.40 & 5.43 & 8.67 & 12.31 & 10.74 & 10.57 \\
\hline $\mathrm{N}_{210}$ & 87.50 & 90.20 & 88.70 & 88.80 & 18.92 & 20.33 & 19.86 & 19.70 & 5.57 & 7.26 & 6.86 & 6.56 & 9.24 & 13.45 & 11.81 & 11.50 \\
\hline RI Mean & 79.40 & 83.75 & 82.38 & & 16.55 & 17.97 & 17.66 & & 3.99 & 5.31 & 4.84 & & 6.61 & 9.82 & 8.64 & \\
\hline$F . t e s t$ & \multicolumn{4}{|c|}{$* *$} & \multicolumn{4}{|c|}{$* *$} & \multicolumn{4}{|c|}{$* *$} & \multicolumn{4}{|c|}{$* *$} \\
\hline$L S D 5 \%$ & \multicolumn{4}{|c|}{0.154} & \multicolumn{4}{|c|}{0.048} & \multicolumn{4}{|c|}{0.060} & \multicolumn{4}{|c|}{0.069} \\
\hline LSD $1 \%$ & \multicolumn{4}{|c|}{0.211} & \multicolumn{4}{|c|}{0.066} & \multicolumn{4}{|c|}{0.095} & \multicolumn{4}{|c|}{0.095} \\
\hline \multirow{2}{*}{$F$. test $\begin{array}{c}\mathrm{I} \\
\mathrm{N}\end{array}$} & \multicolumn{4}{|c|}{$* *$} & \multicolumn{4}{|c|}{$* *$} & \multicolumn{4}{|c|}{$* *$} & \multicolumn{4}{|c|}{$* *$} \\
\hline & \multicolumn{4}{|c|}{$* *$} & \multicolumn{4}{|c|}{$* *$} & \multicolumn{4}{|c|}{$* *$} & \multicolumn{4}{|c|}{$* *$} \\
\hline
\end{tabular}

*Significant at 5\% level. $\quad * *$ Significant at $1 \%$ level.

$\mathrm{RI}=$ Residual effect of Bio-fertilization Inoculations $\quad \mathrm{RI}_{0}=$ Control treatment.

$\mathrm{RI}_{1}=$ Residual effect of Cyanobacteria treatment. $\quad \mathrm{RI}_{2}=$ Residual effect of Cerealen treatment.

$\mathrm{N}=$ Mineral Nitrogen Fertilization $\quad \mathrm{N}_{0}=0 \mathrm{~kg} \mathrm{~N} \mathrm{ha}^{-1} . \quad \mathrm{N}_{70}=70 \mathrm{~kg} \mathrm{~N} \mathrm{ha}^{-1} . \quad \mathrm{N}_{140}=140 \mathrm{~kg} \mathrm{~N} \mathrm{ha}^{-1}$.

$\mathrm{N}_{210}=210 \mathrm{~kg} \mathrm{~N} \mathrm{ha}^{-1}$. 
Table (6) showed that significant increases were ratified in wheat plant height, wheat grain and straw yield and 1000-grain weight by $\mathrm{N}$ bio-fertilizer inoculations as a residual effect. While, Table (7) shows that the residual effect of $\mathrm{N}$ bio-fertilization was a significantly increased NPK uptake in wheat grain, and straw. The residual effect of Cyanobacteria inoculation gave the highest mean values of the previous parameters followed by the residual effect of Cerealen inoculations. These results could be attributed to organic matter produced, by $\mathrm{N}$ bio-fertilizer inoculations and nutrient elements such as NPK released from histolysis of organic matter.

Table 7. The amount of $N, P$ and $K$ uptake in wheat grain, and straw as affected by nitrogen application rates, the residual effect of different inoculations with $\mathbf{N}$ bio-fertilization: $\left(\mathrm{RI}_{0}=\right.$ control, $\mathrm{RI}_{1}=$ Residual effect of Cyanobacteria and $\mathrm{RI}_{2}=$ Residual effect of Cerealen treatment) and their interaction

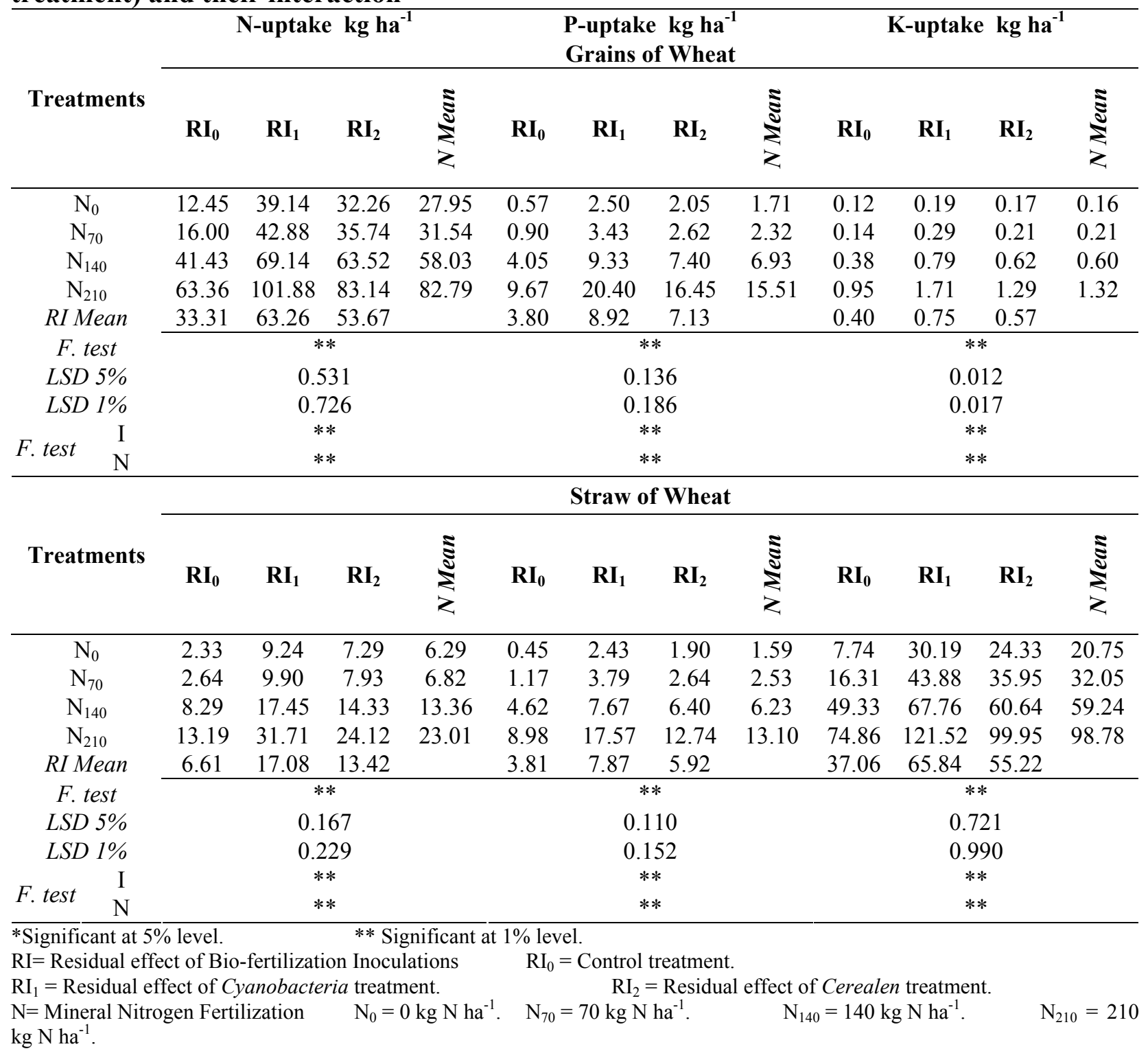


Table 8. Effect of $\mathbf{N}$ bio fertilizer inoculations on some soil $(0-30 \mathrm{~cm})$ chemical properties of the experimental soil after maize harvest in 2013 season

\begin{tabular}{|c|c|c|c|c|c|}
\hline Treatment & $\begin{array}{c}\mathrm{pH} \\
\text { in the soil-water } \\
\text { suspensions } \\
(1: 2.5) \\
\end{array}$ & $\begin{array}{c}\mathrm{N} \\
\text { Extraction by } \\
\mathrm{K}_{2} \mathrm{SO}_{4}\end{array}$ & $\begin{array}{c}\mathbf{P} \\
\text { Extraction by } \\
\mathrm{NaHCO}_{3} \\
\mathrm{mg} \mathrm{kg}^{-1} \\
\end{array}$ & $\begin{array}{c}\mathrm{K} \\
\text { Extraction by } \\
\mathrm{C}_{2} \mathrm{H}_{3} \mathrm{O}_{2} \mathrm{NH}_{4}\end{array}$ & $\underset{\mathrm{g} \mathrm{kg}^{-1}}{\mathrm{OM}}$ \\
\hline $\mathrm{I}_{0}$ & 8.5 & 35 & 8.30 & 467 & 9.2 \\
\hline$I_{1}$ & 7.9 & 79 & 11.34 & 504 & 15.1 \\
\hline $\mathrm{I}_{2}$ & 8.1 & 68 & 10.87 & 490 & 13.4 \\
\hline
\end{tabular}

$\mathrm{I}_{0}=$ Control treatment.

$\mathrm{I}_{1}=$ Cyanobacteria treatment.

$\mathrm{I}_{2}=$ Cerealen treatment.

Therefore, soil fertility increase and supplying wheat plants with nutrients, which increase the final yield. Faujdar and Sharma, (2013) found the similar results when applying bifertilizers viz., Azotobacter, VAM and Azotobacter + VAM inoculation on maize, where they obtained high yields of succeeding wheat grown in sequence. In addition, (Zulpa et al., 2008; Ghazal et al., 2013 and Grzesik et al., 2013) found that using Cyanobacteria inoculation on maize had an effect optimized for the properties of the soil and thus improve the subsequent crop.

\section{The interaction effect:}

Tables $(5,6$ and 7$)$ showed that the highest previous wheat parameters except the maize stover yield were obtained by the residual effect of Cyanobacteria inoculation with $210 \mathrm{~kg} \mathrm{~N} \mathrm{ha}^{-1}$ followed by the residual effect of Cerealen inoculation with $210 \mathrm{~kg} \mathrm{~N} \mathrm{ha}^{-1}$, while, the highest value of maize stover yield were obtained by $\mathrm{RI}_{1} \mathrm{~N}_{210}$ followed by $\mathrm{RI}_{1} \mathrm{~N}_{140}$. At the same time, the results indicated in (Table 6) that grain yield of wheat with $\mathrm{RI}_{1} \mathrm{~N}_{140}$ was greater than grain yield with $\mathrm{RI}_{0} \mathrm{~N}_{210}$, also straw yield of wheat with $\mathrm{RI}_{1} \mathrm{~N}_{140}$ and $\mathrm{RI}_{2} \mathrm{~N}_{140}$ was higher than stover yield with $\mathrm{RI}_{0} \mathrm{~N}_{210}$. Thus, it can be concluded that the residual effect of Cyanobacteria or Cerealen treatments applied with previous maize cultivation on sequent wheat cultivation besides mineral nitrogen fertilizer can save about $70 \mathrm{~kg}$ $\mathrm{N} \mathrm{ha}{ }^{-1}$ of its total nitrogen requirement which is very important from the economical point of view. These results might be explained on the basis that the promoting effects of the residual effect of bio-fertilizer and nitrogen together on subsequent wheat growth were reflected in the increased of all studied parameters.

Effect of $\mathbf{N}$ bio-fertilizer on soil properties after maize harvest:

Data in Table (8) showed that applying $\mathrm{N}$ biofertilizer influenced some soil properties and subsequently increased the fertility and productivity of the soil. Available amount of N,P and K and organic matter content increased while soil $\mathrm{pH}$ in the root zone decreased by using Cyanobacteria and Cerealen inoculations. In this respect, NPK elements could be increased with $\mathrm{pH}$ reduction in the root zone by biofertilizer inoculations, Potassium element in soil could be released from soil (clay) minerals due to organic acids by hydrolysis or solution processes caused by organic acids and available phosphorus could be increased in soil because of the excretions of organic acids by bio-fertilizer inoculation which convert slight soluble $\mathrm{CO}_{3}\left(\mathrm{PO}_{4}\right)_{2}$ to soluble di-and monobasic phosphates. Gholami, et al. (2012) reported that plant growth promoting Rhizobacteria (PGPR) plays an important role in soil fertility. Zulpa, et al. (2008) studied the effect of cyanobacterial products of Tolypothrix tenuis and Nostoc muscorum on the microbiological activity and the nutrient content of the soil underlying the remains of maize and on the degradation of remains. They indicated that the biomass and extracellular products of both strains increased the soil microbial activity such as total nitrogen (10\%: $12 \%)$ and available phosphorus (22\%: $32 \%)$.

\section{CONCLUSION}

It can be concluded that the application of mineral $\mathrm{N}$ at a rate of $280 \mathrm{~kg} \mathrm{ha}^{-1}$ with Cerealen and Cyanobacteria can increase the maize grain yield by 4.14 to $19.25 \%$ and the maize stover yield by 6.89 to $16.98 \%$. Also applying bio-fertilization on the previous maize crop with two third doses of recommended nitrogen can produce an economic yield of subsequent wheat crop. Wheat fertilized at a rate of $140 \mathrm{~kg} \mathrm{~N} \mathrm{ha}^{-1}$ after maize cultivation that inoculated with Cyanobacteria gave higher yield of grain and straw than they fertilized with $210 \mathrm{~kg} \mathrm{~N} \mathrm{ha}^{-1}$ thus saving $70 \mathrm{~kg}$ $\mathrm{N} \mathrm{ha}^{-1}$ with a healthy and high production.

\section{REFERENCES}

Aarti V. and G. S. Tomar. 2014. Effect of planting geometry and nitrogen levels on growth, green cob yield and economics of sweet corn (Zea mays Saccharata Sturt.). Inter. J. Agric. Sci., 10 (2): 766-769. 
Aguilar C., J. A. S. Escalante-Estrada, Aguilar-Mariscal, J. A. Mejía-Contreras, V. F. Conde-Martínez and A. TrinidadSantos. 2015. Grain yield and profitability in corn as a function of genotype, bio-fertilizer and nitrogen, under warm climate. Tropical and Subtropical Agroecosystems, 18 (2): 151-163.

Aishwath O. P., M. S. Dravid and P. S. Deshmukh. 2003. Nitrate reductase activity and chlorophyll content in wheat as influenced by chemical fertilizers, bio-fertilizers and farmyard manure. Annals of Agric. Res. India, 24 (3): 466-473.

Aminzadeh H. and M. R. Namazari. 2013. Effect of different amount of mineral nitrogen and biological fertilizer on yield and yield components of corn. J. Agric. Biolog. Sci., 8 (6): 487-492.

Arnon D. I. 1949. Copper enzyme in isolated chloroplasts, polyphenol oxidase in Beta vulgaris. Plant Physiol., 24: 115.

CoHort Software. 2008. CoStat version 6.400.

El-Kholy M. H. 1997. Effect of soil irrigation levels, algalization and nitrogen application on rice and soil properties. Ph. D Thesis. Fac. Agric. Mansoura Univ. Egypt.

Faizy S. E. D. A., M. M. Rizk, E. A. E. Gazia and M. M. A. Amer. 2011. Effect of nitrogen and potassium fertilizer application at physiological growth stages on yield of two wheat varieties grown in the north middle delta. Alex. Sci. Exch. J., 32 (1): 40-50

Faujdar R. S. and M. Sharma. 2013. Effect of FYM, biofertilizers and Zinc on yield of maize and their residual effect on wheat. J. Soils Crops, 23(1): 41-52.

Ghazal F. M., M. B. A. El-Koomy, Kh. A. Abdel-Kawi and M. M. Soliman. 2013. Impact of Cyanobacteria, Humic Acid and Nitrogen Levels on Maize (Zea Mays L.) Yield and Biological Activity of the Rhizosphere in Sandy Soils. J. Am. Sci, 9(2): 46-55.

Gholami A., A. Biyari., M. Gholipoor and H. A. Rahmani. 2012. Growth Promotion of Maize (Zea mays L.) by PlantGrowth-Promoting Rhizobacteria under Field Conditions. Communications in Soil Sci. Plant Analysis, 43 (9): 1263 1272.

Grzesik M., Z. Romanowska-Duda and R. Janas. 2013. Application of green algae and Cyanobacteria secondary metabolites in corn biomass for eco-energy production. VI International Scientific Symposium, Farm Machinery and Processes Management in Sustainable Agriculture, Lublin, Poland, 79-81.

Hesse P. R. 1971. A Text Book of Soil Chemical Analysis. Juon Murry (Publisher) 1td, London .

Jackson M. L. 1967. Soil Chemical Analysis. Prentice-Hall of India, New Delhi .

Jackson M. L. 1973. Soil Chemical Analysis. Prentice-Hall of India private limited, New Delhi.
Kennedy I. R., A. T. M. A. Choudhury and M. L. Kecskes. 2004. Non-symbiotic bacterial diazotrophs in cropfarming systems: can their potential for plant growth promotion be better exploited?. Soil Biology and Biochemistry. Oxford, UK, Pergamon Press., 36 (8): 1229-1244.

Kopsell D. A., D. E, Kopsell, M. G. Lefsrud, J. CurranCelentano and L. E. Dukach. 2004. Variation in lutein, bcarotene, and chlorophyll concentrations among Brassica oleracea cultigens and seasons. Hort. Sci., 39 (2): 361364.

Mahato P., A. Badoni and J. S. Chauhan .2009. Effect of Azotobacter and nitrogen on seed germination and early seedling growth in tomato. Researcher, 1: 62-66.

McIntyre G. I. 2001. Control of plant development by limiting factors: a nutritional perspective. Physiol. Plantarum, 113: $165-175$.

Olsen S. R. and L. A. Dean. 1965. Method of Soil Analysis. Part 2 C.A. Black, Editor-in-chief. P. 1035-1049. Am. Soci. Agron. USA.

Paul E. A. and F. E. Clark. 1989.Soil Microbilogy and Biochemistry. Academic Press, Inc., New York.

Piper C. S. 1950. Soil and Plant Analysis. Inter. Sci. Publishers Inc. New York.

Radwan F. I. and M. A. A. Nassar. 2011. Response of Maize Hybrid to Biofertilization, Soil Nitrogen Application and Weed Control. Alex. Sci. Exch. J., 32 (4): 409-421.

Ravikumara S., K. Kathiresanb, S. Thadedus Maria Ignatiammalc, M. Babu Selvama and S. Shanthya. 2004. Nitrogen-fixing Azotobacters from mangrove habitat and their utility as marine bio-fertilizers. J. Experim. Marine Biology Ecology, 312: 5-17.

Sachin D. N. and P. Misra. 2009. Effect of Azotobacter chroococcum (PGPR) on the Growth of Bamboo (Bambusa bamboo) and Maize (Zea mays) Plants. Biofrontiers, 1 (1): 24-31.

Schlemmer M. R., D. D. Francis, J. F. Shanahan and J. S. Schepers. 2005. Remotely Measuring Chlorophyll Content in Corn Leaves with Differing Nitrogen Levels and Relative Water Content. Agron. J., 97 (1): 106-112 .

Snedecor G.W. and W. G. Cochran. 1967. Statistical Methods, $4^{\text {th }}$ Edition, Iowa State Univ. Press, Ame. Iowa, USA.

Stevenson F. J. 1982. Nitrogen in Agricultural Soils. Agron. Monogr. 22. ASA, CSSA, and SSSA, Madison, WI.

Sushila R. and G. Gajendra. 2000. Influence of farmyard manure, nitrogen and bio-fertilizers on growth, yield attributes and yield of wheat (Triticum aestivum) under limited water supply. Indian J. Agron., 45 (3): 590-595.

Witty J. F., Keay, P. J., Frogatt, P. J. and Dart, P. J. 1979. Algal nitrogen fixation on temperate arable fields. The Broadbalk experiment. Plant Soil, 52: 151-164.

Yash P. K. 1998. Handbook Reference Methods for Plant Analysis. CRC Press Boca Raton Boston London New York Washington, D.C. 
Yasin M., A. Kaleem, M. Waqas and T. Asif. 2012. Biofertilizers, substitution of synthetic fertilizers in cereals for leveraging agriculture. Crop Environ., 3 (1-2): 62-66.

Zahir Z. A., H. N. Asghar, M. J. Akhtar and M. Arshad. 2005. Precursor (L-tryptophan)-inoculum (Azotobacter) interaction for improving yields and nitrogen uptake of maize. J. Plant Nutr., 28 (5): 805-817.
Zulpa G., M. F. Siciliano, M. C. Zaccro, M. Storni and M. Palma. 2008. Effect of Cyanobacteria on the soil microflora activity and maize remains degradation in a culture chamber experment. Int. J. Agric. Biol., 10 (4): 388-392.

\section{الملغص العري \\ تأثير النسميد النيتروجيف المعنف والحيوى عل محصط الذرة اللشامية وعل بهض خواص الترية و

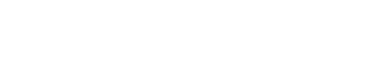 \\ إبراهيمسعيد محمد مسعد}

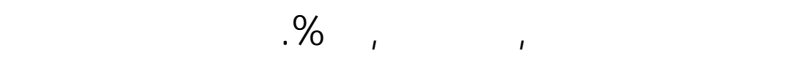
ظٔلهرت النتائج أن ظبيق الأسمة الحيوي ـة النيتروجيني يمكن أن تتنج محصول عاله من حبوب الذرة عند لستخدل

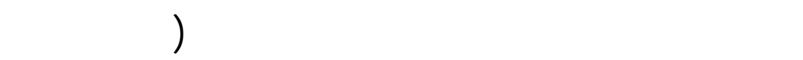

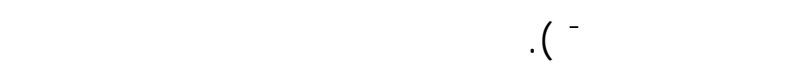

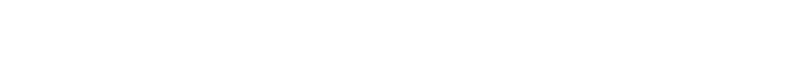

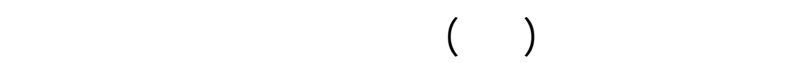

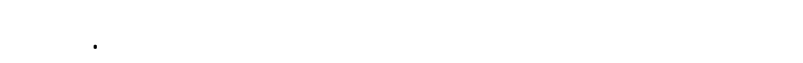

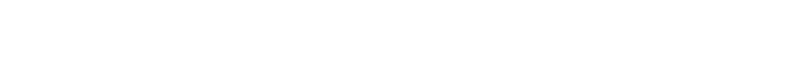

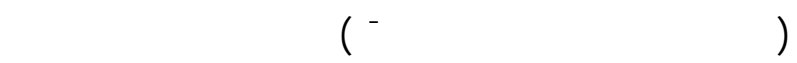

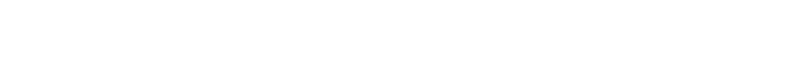

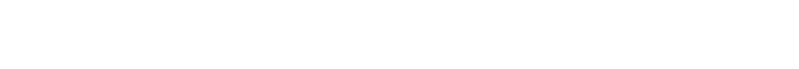

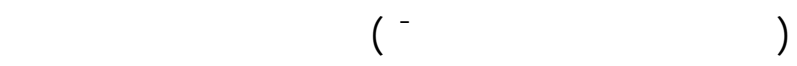

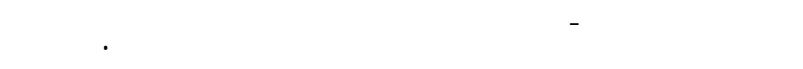
يتعلق بخصائص التربة بعد حصاد الذرة للثلمية أوضحت

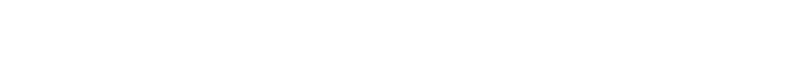

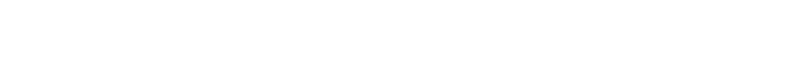

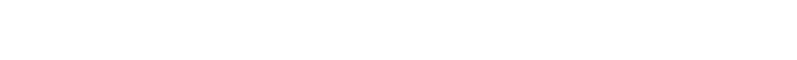

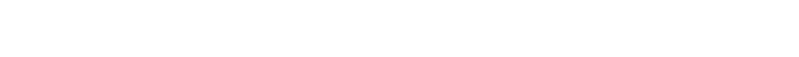
رقم حموضة التربة فى مطق ـة الج ذذور عذ ـد لـد ـتخدلم الطحالب الخضراء المزرقة وللسيريالين.
أقيمت تجربتان حقليتلن فـ مهطة البحوث الزراعي ـة

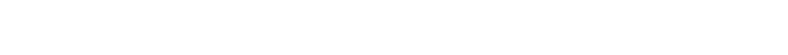

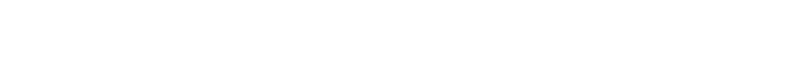
النيتروجين الحيوى(طحالب خضراء مزرقة -سد -ريالين)

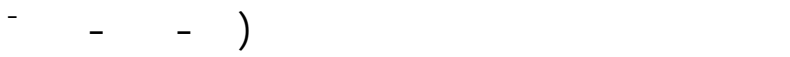

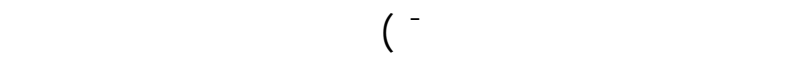
العناصرلمحصول الذرة اللثمية وكذك درلسة الأثر المتقى للتسميد النيتروجيف الحيوى على المحصول اللاحق(القمح)

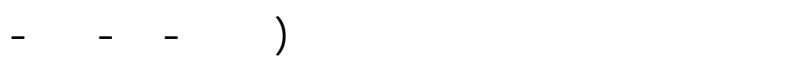

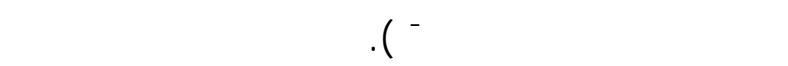

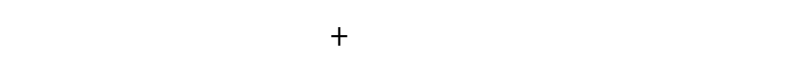

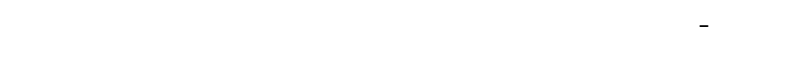

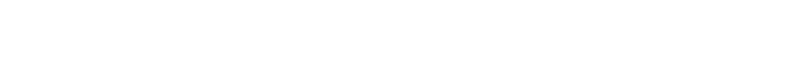

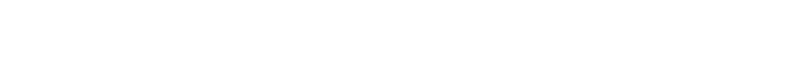

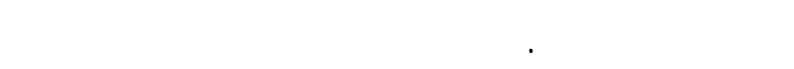

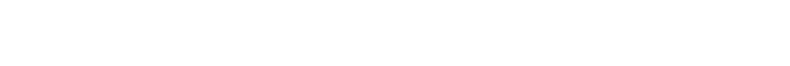

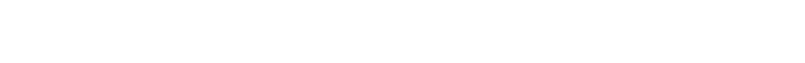

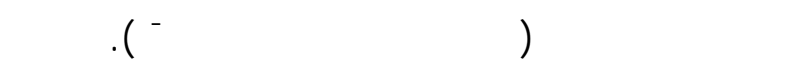

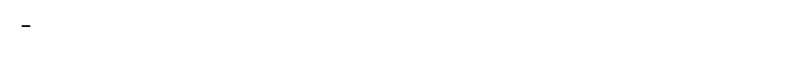

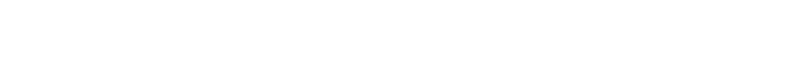

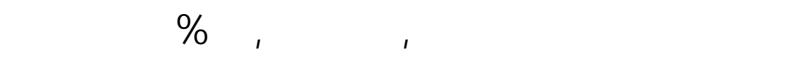

